\title{
Mercury concentration in the freshwater bonefish Cyphocharax gilbert (Curimatidae) and its parasite the crustacean Riggia paranensis (Cymothoidae)
}

\author{
Débora C. Lins ${ }^{1}$, Maria E. Meirelles², Olaf Malm³ and Neuza R. W. Lima ${ }^{4}$
}

Fish parasites can accumulate heavy metals reaching higher concentrations than the host and may affect the host's bioaccumulation. The present study compared total mercury concentration in the liver and muscle of Cyphocharax gilbert and in the parasite Riggia paranensis sampled in the middle Itabapoana River, Brazil, also considering the reproductive stages of both fish and parasite. Mean concentrations of mercury in muscle of fish varied from $20.8 \mathrm{ng} \cdot \mathrm{g}^{-1}$ in mature females to $38.1 \mathrm{ng} . \mathrm{g}^{-1}$ in postspawning females. The mean concentrations in fish liver varied from $60.9 \mathrm{ng} / \mathrm{g}$ in post-spawning females to $110.4 \mathrm{ng}^{-\mathrm{g}^{-1}}$ in infested males. The mean concentration of mercury in parasites varied from $26.2 \mathrm{ng} \cdot \mathrm{g}^{-1}$ in specimens carrying early embryo to $39.5 \mathrm{ng} \cdot \mathrm{g}^{-1}$ in specimens with eggs. Positive and significant associations $(P \leq 0.05)$ were found between the total mercury concentrations in parasites and muscle of host (both females and males), and between concentrations in parasites and in the liver of male hosts. These results suggest that $R$. paranensis can be used to indicate mercury levels in edible parts of C. gilbert.

Parasitos de peixes podem acumular metais pesados em concentrações acima dos hospedeiros, podendo afetar a bioacumulação nestes. O presente estudo comparou a concentração total do mercúrio no fígado e no músculo de Cyphocharax gilbert e no parasito Riggia paranensis, coletados no trecho médio do rio Itabapoana, Brasil, considerando o estágio reprodutivo tanto dos peixes como dos parasitos. A concentração média do mercúrio nos músculos dos peixes variou entre 20,8 ng. $\mathrm{g}^{-1}$ nas fêmeas maturas e 38,1 ng.g ${ }^{-1}$ nas fêmeas desovadas. As concentrações médias nos fígados dos peixes variaram entre 60,9ng/g em fêmeas desovadas e 110,4 ng. . $^{-1}$ em machos parasitados. Entre os parasitos, as concentrações médias de mercúrio variaram entre 26,2 ng. $\mathrm{g}^{-1}$ em espécimes com embriões iniciando o desenvolvimento to 39,5 ng. $\mathrm{g}^{-1} \mathrm{em}$ espécimes com ovos . Associações positivas e significativas $(P \leq 0.05)$ foram encontradas entre as concentrações totais de mercúrio em parasitos e músculos dos hospedeiros (tanto em macho como em fêmeas) e entre as concentrações nos parasitos e os fígados dos hospedeiros machos. Estes resultados sugerem que o parasito $R$. paranensis pode ser utilizado como bioindicador dos níveis de mercúrio nas partes comestíveis de C. gilbert.

Key words: Heavy metal, Bioaccumulation, Parasitic castration, Reproduction.

\section{Introduction}

Fish are typically infested with many species of parasites within the gills, digestive tract and other tissues. Knowledge of the parasites is important not only to learn about fish health but also to evaluate environment quality (Sures, 2001). In aquatic habitats, the use of fish parasites as bioindicators of pollution has been demonstrated to be particularly suitable due to their capacity of bioconcentration (Sures et al., 1999; Sures, 2001; Sures et al., 2003).
Certain fish parasites, particularly intestinal acanthocephalans and cestodes, are widespread and common fish parasites, and they can accumulate heavy metals at concentrations significantly higher than those in host tissues or the environment (Sures, 2001, 2003, 2004; Sures et al., 2003; Schludermann et al., 2003; Thielen et al., 2004; Tekin-Ozan \& Kir, 2005). These parasites have been indicated as tools for monitoring of heavy metal pollution by $\mathrm{Cd}, \mathrm{Cu}, \mathrm{Pb}$, and $\mathrm{Zn}$, among others. However, the bioaccumulation of high concentrations of heavy metals such as $\mathrm{Cd}, \mathrm{Cr}$, and $\mathrm{Pb}$

\footnotetext{
${ }^{1}$ Eságua, Avenida das Américas, 19019 - Sala 301 D - Recreio dos Bandeirantes, 22790-701 Rio de Janeiro, RJ, Brazil. debylins@terra.com.br ${ }^{2}$ Universidade Federal de Santa Catarina (UFSC), Trindade, 88040-900 Florianópolis, SC, Brazil. meirellesmaria@ig.com.br ${ }^{3}$ Universidade Federal do Rio de Janeiro (UFRJ), Ilha Fundão, Inst. Biofisíca Carlos Chagas Filho, Laboratório de Radioisótopos, 21949900 Rio de Janeiro, RJ, Brazil. olaf@biof.ufrj.br

${ }^{4}$ Universidade Federal Fluminense, Instituto de Biologia, Laboratório de Ecologia de Peixes, Cx. Postal, 100436, 24001-097 Niterói, RJ Brazil.rejanewille@uol.com.br
} 
observed in some parasites related to their hosts cannot be due to biomagnification. Only mercury can be involved in biomagnification within the host-parasite relation (Bergey et al., 2002).

The location of the parasites within the host can also be another important factor to be considered in bioaccumulation studies. Most studies conducted to evaluate the use of fish parasites as bioindicators of heavy metals have selected the parasites as sentinels (Sures et al., 1999, 2003; Sures, 2001). Eco-parasites such as monogeneans and crustaceans were not indicated as sentinels because they can be affected by surrounding water and because most are probably similar in their bioaccumulation pattern related to free-living specimens (Sures, 2004). However, the parasite Probopyrus pandalicola (isopod crustacean, hematophagous in gill chamber) was able to reduce the mercury concentrations in its host, the grass shrimp Palaemonetes pugio (Bergey et al., 2002).

The parasite Riggia paranensis Szidat, 1948 is one isopod crustacean species that infests species of Cyphocharax (Bastos \& Thatcher, 1997). Like some species of the family Cymothoidae, only females are parasites (Raibaut \& Trilles, 1993). Adult females of this species are blood feeders and once infesting a fish, it does not switch to another host. These females grow inside a host-produced capsule in the pericardial area, where they obtain blood from the gills and maintain an opening in the host body to obtain oxygen from the water and to deliver their brood into the environment (Raibaut \& Trilles, 1993). The males of $R$. paranensis are free-living specimens, being smaller than females (Bastos \& Thatcher, 1997). They can be found inside the fish in a copulation position since they usually cling to the females near the base of the pleopods (Bastos \& Thatcher, 1997; Huizinga, 1972; Thatcher, 1991).

The host Cyphocharax gilbert (Quoy \& Gaimard, 1824) feed on microalgae associated with mud that accumulates on the bottom of lagoons and river puddles (Sazima \& Caramaschi, 1989). This species is commonly found in coastal drainages of eastern Brazil, being distributed in rivers and lagoons of the states of Bahia, Espírito Santo and Rio de Janeiro (Vari, 1992) and shows the highest fecundity among the known members of the Curimatidae (Azevedo et al., 1938). The populations of this species have a spawning period of two annual reproductive cycles, beginning in February and August (Azevedo et al., 2002; Lima et al., 2007). However, C. gilbert shows parasitic castration when infested by the crustacean $R$. paranensis, being unable to reproduce (Azevedo et al., 2002, 2006; Gomes da Silva et al., 2005; Lima et al., 2007). Infested fish lack gonadal development and two sex-specific proteins in the plasma (Gomes da Silva et al., 2005), and they have low levels of sex steroids (Lima et al., 2007). The prevalence of parasitism in the fish C. gilbert varies from place to place, but it is around $60 \%$ in the middle Itabapoana River (Azevedo et al., 2002, 2006), an area that became a target for gold mining in the middle 1980's (Malm et al., 1989b; Torres et al., 1991). In the upper and middle part of the river, it can be observed that domestic and industrial effluents reduce water quality. The impact of these activities was revealed by the levels of eleven heavy metals in river sediments, including arsenic and mercury (Malm et al., 1989a, 1989b; Torres et al., 1991).

The aim of the present study was to compare total concentration of mercury in the muscle and liver of the fish $C$. gilbert and its parasite $R$. paranensis from the middle Itabapoana River, considering the sex of the host and the reproductive stages of both fish and parasite.

\section{Materials and Methods}

Specimens of C. gilbert were obtained from local fishermen in the middle Itabapoana River (Rio de Janeiro/Espírito Santo states, southeastern Brazil; $21^{\circ} 15^{\prime} \mathrm{S}$ and $42^{\circ} 30^{\prime} \mathrm{W}$ ). Fishermen collected the specimens using two types of gillnet (three of them with $20-\mathrm{mm}$ mesh, $25 \mathrm{~m}$ long and $1.5 \mathrm{~m}$ wide; the other three with $25-\mathrm{mm}$ mesh, $25 \mathrm{~m}$ long and $1.5 \mathrm{~m}$ wide). Gillnets were kept in the river for $12 \mathrm{~h}$, from sunset to sunrise in January, June, September and October of 2003 and March, October and November of 2004.

The standard length (cm - distance from the tip of snout to the fork of caudal fin) of the fish was measured using live specimens to determine their body size. Fish were maintained in cold water $\left(0^{\circ} \mathrm{C}, 5 \mathrm{~min}\right.$.) to reduce sensitivity (Lima et al., 2007), sacrificed by decapitation and classified by the presence of the parasite, by sex (male or female), and by gonadal development (initial development, maturating, mature, postspawning, and inhibited by position, color and size of gonads), according to Azevedo et al. (2002). Parasites were removed from the host-produced capsule in the pericardial area to determine their total length ( $\mathrm{mm}$ - distance from the tip of head to the end of the telson). The prevalence of parasitism was calculated as the number of infested fish / number of examined fish x 100\%, according to Bush et al. (1997).

Portions of muscle free of scales and skin and of liver were obtained from each fish in the field. All materials (liver, muscle and parasites) were individually packed in polyethylene bags and frozen $\left(-10^{\circ} \mathrm{C}\right)$ in the field, during a 12$\mathrm{h}$ period before transporting them under cold conditions to the laboratory. A small portion of reproductive tissues was collected from the marsupial cavity of parasites and preserved in $70 \%$ ethanol. These reproductive tissues were analyzed with a stereomicroscope with epi-illumination (Zeiss, stemi SV 11) to classify the parasites into four reproductive stages, considering the morphological characteristics shape, bilateral symmetry, emergent structures, pigmentation degree, and body segmentation of eggs or embryos (Azevedo, 2002).

Muscle and liver samples and parasites were handled using the same procedures. The samples were defrosted, cut into small fractions, and weighed to obtain aliquots of $400 \mathrm{mg}$ each to be digested in a hot-water bath at $60^{\circ} \mathrm{C}$ with a mixture 
of $1.0 \mathrm{~mL}$ of $\mathrm{H}_{2} \mathrm{O}_{2}$ and $3.0 \mathrm{~mL}$ of $\mathrm{H}_{2} \mathrm{SO}_{4} / \mathrm{HNO}_{3}$ (1:1) until the dissolution of all material. After cooling, $5.0 \mathrm{~mL}$ of $\mathrm{KMnO}_{4}$ (5\%) were added. The samples were warmed over a water bath at $60^{\circ} \mathrm{C}$ for $15 \mathrm{~min}$ and allowed to stand overnight, then neutralized with a $12 \% \mathrm{NH}_{4} \mathrm{Cl}+\mathrm{NaCl}$ solution, and made up to a final volume of $25 \mathrm{~mL}$ with Milli-Q $\mathrm{H}_{2} \mathrm{O}$ in the trial balloon.

Mercury analyses were performed by atomic absorption spectrometry with an AA 1475 Varian instrument equipped with a cold-vapor generator accessory (Varian VGA-76), with sodium borohydride as a reducing agent at the Laboratório de Radioisótopos Eduardo Penna Franca of the Federal University of Rio de Janeiro, following the method of Malm et al. (1989b). Reproducibility and accuracy were determined by means of duplicate analyses. The Hg concentration levels were expressed in ng.g ${ }^{-1}(\mathrm{ppb})$, based on wet weight. Analytical quality control was carried out with the use of a certified reference (Malm et al., 1989b).

The Mann-Whitney test was applied to determine if body sizes were significantly different between females and males of fish, regarding infested condition, and to test if body sizes of parasites were significantly different, regarding sex of host. Non-parametric analysis of variance (Kruskal-Wallis test) tested if the reproductive condition of each species significantly affected the results of total mercury concentrations in fish tissues (liver and muscle) or parasite. This test was also applied to see if parasitism affected the results of total mercury concentrations in muscle and liver of hosts. Spearman correlation coefficient $\left(r_{s}\right)$ was applied to determine if there was any relationship between the concentrations in muscle and liver of fish, and between the concentrations of mercury in parasites and in muscle or liver of their hosts (Snedecor \& Cochran, 1971).

Four specimens of $C$. gilbert infested by $R$. paranensis were deposited at the Coleção Zoológica Didática, Universidade do Norte Fluminense (UENF/CY 1998/01-04). Vouchers were deposited at the Museu Nacional do Rio de Janeiro (MNRJ 30982).

\section{Results}

The parasite prevalence was $58.0 \%$ among the collected fish. Most of the fish were infested by only one parasite (46\%). Specimens of fish with two parasites represented 12\% of the sample. A total of 98 females and 69 males of fish and 174 parasites ( 74 from female hosts and 89 from male hosts) were analyzed. Standard length of fish varied from $10.6 \mathrm{~cm}$ to $19.7 \mathrm{~cm}$, but no differences were observed between females and males, between non-infested or infested females or between non-infested or infested males regarding average body size (Table 1). Total length of parasites varied from 1.1 $\mathrm{mm}$ and $3.0 \mathrm{~mm}$, and no differences in body size were observed between the parasites removed from female hosts and those removed from male hosts (Table1).

Mean $\mathrm{Hg}$ concentrations in muscle varied from 20.8 ng.g ${ }^{-1}$ in mature females to $38.1 \mathrm{ng} \cdot \mathrm{g}^{-1}$ post-spawning females (Table 2). The differences in Hg mean concentration among non-infested females or non-infested males at different gonad development stages were not significant $(P>0.05)$. Non-significant differences $(P>0.05)$ in concentration were also observed between non-infested

Table 1. Body size (mean and standard deviation ( \pm SD) of the fish Cyphocharax gilbert (standard length, $\mathrm{cm}$ ) and of the parasite Riggia paranensis (total length, $\mathrm{mm}$ ), from the middle Itabapoana River, Brazil. (*) Only females were parasites (Bastos \& Thatcher, 1997).

\begin{tabular}{|c|c|c|c|c|c|}
\hline \multirow[b]{2}{*}{ Species } & \multirow[b]{2}{*}{ Sex } & \multirow[b]{2}{*}{ Condition } & \multicolumn{3}{|c|}{ Body size } \\
\hline & & & (n) & Mean & ( \pm S.D. $)$ \\
\hline \multirow[t]{4}{*}{ C. gilbert } & Female & Non-infested & 66 & 15.1 & 1.9 \\
\hline & & Infested & 35 & 14.9 & 1.7 \\
\hline & Male & Non-infested & 28 & 15.1 & 1.8 \\
\hline & & Infested & 40 & 15.1 & 1.5 \\
\hline \multirow[t]{2}{*}{$R$. paranensis } & Female* & Female Host & 66 & 2.1 & 0.3 \\
\hline & & Male Host & 74 & 2.2 & 0.3 \\
\hline
\end{tabular}

Table 2. Total mercury concentrations (mean \pm SD and range in ng. ${ }^{-1}$ wet weight) in muscle and liver of Cyphocharax gilbert fish non-infested and infested by Riggia paranensis at different reproduction stages, from the middle Itabapoana River, Brazil. The gonadal development stages are: ID, initial development; M1, maturating; M2, mature; PS, post-spawning, and IN, inhibited by parasitism.

\begin{tabular}{|c|c|c|c|c|c|c|c|c|}
\hline \multirow[t]{2}{*}{ Sex } & \multirow[t]{2}{*}{ Condition } & \multirow[t]{2}{*}{ Stage } & \multicolumn{3}{|c|}{ Muscle } & \multicolumn{3}{|c|}{ Liver } \\
\hline & & & (n) & Mean & $( \pm \mathrm{SD})$ & (n) & Mean & $( \pm \mathrm{SD})$ \\
\hline \multirow[t]{5}{*}{ Female } & Non- & ID & 18 & 31.1 & 19.9 & 18 & 74.4 & 35.1 \\
\hline & Infested & M1 & 10 & 25.7 & 17.8 & 10 & 85.4 & 45.0 \\
\hline & & M2 & 10 & 20.8 & 10.5 & 9 & 75.0 & 24.8 \\
\hline & & PS & 16 & 38.1 & 15.4 & 16 & 60.9 & 26.5 \\
\hline & Infested & IN & 38 & 32.1 & 18.1 & 35 & 96.1 & 57.6 \\
\hline \multirow[t]{3}{*}{ Male } & Non- & ID & 15 & 30.0 & 19.9 & 15 & 85.4 & 46.9 \\
\hline & Infested & M2 & 14 & 23.6 & 13.9 & 14 & 61.7 & 25.6 \\
\hline & Infested & IN & 40 & 33.1 & 21.2 & 42 & 110.4 & 52.8 \\
\hline
\end{tabular}


and infested males or females for both muscle and liver tissues.

The mean concentration of mercury in parasites varied from 26.2.5ng. $\mathrm{g}^{-1}$ in females carrying early embryos to 39.5ng.g ${ }^{1}$ in females with eggs (Table 3). Non-significant differences $(P>0.05)$ in concentration were observed among parasites at different reproductive stages.

The results obtained from each fish tissue (muscle and liver) (Table 2) and from the parasites (Table 3) were compared, only considering fish sex (male or female) and its parasitic condition (non-infested and infested) (Table 4). The concentrations of mercury in the liver of non-infested fish were on average 2.6 times higher than in muscle. Among infested fish, the concentrations of mercury in the liver were on average 3.2 times higher than for muscle. These concentrations of mercury in muscle of host were similar to the concentrations obtained in their parasites. The concentrations in the liver of hosts were on average 3.2 times higher than in their parasites.

The concentrations of mercury in muscle of non-infested fish were not significantly different from those in infested ones for both males and females $(P>0.05)$. The mean concentrations of mercury in liver of infested fish were higher than in non-infested ones, but the differences were not significant $(P>0.05)$.

Spearman correlation coefficient $\left(r_{s}\right)$ analysis revealed a significant $(P \leq 0.05)$ and positive association between the total mercury concentration in the muscle of fish (both females and males) and the parasites, and in the liver of males and the parasites (Table 5).

Table 3. Total mercury concentrations (mean \pm S.D. and range in ng. ${ }^{-1}$ wet weight) in the parasite Riggia paranensis at four different reproductive stages, from the middle Itabapoana River, Brazil.

\begin{tabular}{lccc}
\hline Reproductive phase & $(\mathrm{n})$ & Mean & $( \pm$ SD $)$ \\
\hline Egg & 47 & 39.5 & 23.2 \\
Early Embryo & 26 & 26.2 & 14.2 \\
Developed Embryo & 21 & 27.1 & 18.1 \\
Empty Female & 52 & 28.7 & 23.9 \\
\hline
\end{tabular}

\section{Discussion}

The extraction of alluvial gold, indiscriminate use of agrotoxins, and some domestic and industrial effluents have increased the concentration of mercury in several environments around the world, and have been particularly well described in Canadian biota (Fisk et al., 2005). The analyses of fish muscle have allowed the assessment of how humans have been exposed to mercury and the evaluation of detrimental effects on animals at higher trophic levels, especially in gold mining areas (Uryu et al., 2001). The mercury concentrations reported in the edible part of the fish collected from several Brazilian freshwater environments varies from 20 ng. $^{-1}$ to 700 ng.g ${ }^{-1}$ in non-piscivorous species and from 60 ng.g ${ }^{-1}$ to 1,000 ng.g g $^{-1}$ in piscivorous ones (Lacerda et al., 1994; Malm et al., 1995; Lacerda, 1997; Bidone et al., 1997a, 1997b; Lebel et al., 1997; Moraes et al., 1997; Castilhos et al., 1998; Brabo et al., 1999; De Souza et al., 2000; Lechler et al., 2000; Lima et al., 2000; Leady \& Gottgens, 2001; Uryu et al., 2001; Da Silva et al., 2005; Farias et al., 2005; Fostier et al., 2005). The levels of mercury in the edible part of C. gilbert, a nonpiscivorous fish, were close to the lowest values reported for Brazilian fish, suggesting that there is currently a low impact of mercury in the middle Itabapoana River food chains.

Usually the liver is not an edible part of fish, but this organ has been used to assess the biological effects of anthropogenic contaminants in wildlife. Liver is a metabolically active organ, in which metals primarily tend to concentrate and are then metabolized and excreted. Mercury concentrations in liver of $C$. gilbert were approximately double those found in muscle, which matches well with the results of other studies (Agusa et al., 2004; Storelli et al., 2005). An association between mercury concentration in muscle and liver is not a general rule, as observed for C. gilbert. Mercury concentration in liver of the host was three times higher than in the parasite. The opposite pattern was observed for the concentration of lead $(\mathrm{Pb})$ and cadmium $(\mathrm{Cd})$ in freshwater fish and the parasites belonging to the acanthocephalan and cestode groups (Sures et al., 1999).

Positive associations between mercury concentration in muscle and parasites were observed in both male and female host fish. However, a very low ratio of mercury concentration

Table 4. Total mercury concentrations (mean \pm S.D. and range in ng. $\mathrm{g}^{-1}$ wet weight) in muscle and liver of non-infested and infested specimens of Cyphocharax gilbert and in the parasite Riggia paranensis obtained from female or male hosts, from the middle Itabapoana River, Brazil. (*)Only females were parasites (Bastos \& Thatcher, 1997).

\begin{tabular}{|c|c|c|c|c|c|c|}
\hline \multirow[b]{2}{*}{ Species } & \multirow[b]{2}{*}{ Sex } & \multirow[b]{2}{*}{ Condition } & \multirow[b]{2}{*}{ Tissue } & \multicolumn{3}{|c|}{ Total mercury concentration } \\
\hline & & & & (n) & Mean & $( \pm \mathrm{SD})$ \\
\hline \multirow{8}{*}{ C. gilbert } & Female & Non-infested & Muscle & 60 & 31.2 & 19.2 \\
\hline & & & Liver & 58 & 74.0 & 35.4 \\
\hline & & Infested & Muscle & 38 & 32.1 & 18.1 \\
\hline & & & Liver & 35 & 96.1 & 57.6 \\
\hline & Male & Non-infested & Muscle & 29 & 26.9 & 17.3 \\
\hline & & & Liver & 29 & 74.0 & 39.4 \\
\hline & & Infested & Muscle & 40 & 33.1 & 21.2 \\
\hline & & & Liver & 42 & 110.4 & 52.8 \\
\hline \multirow[t]{2}{*}{ R. paranensis } & Female* & Female Host & All & 74 & 30.1 & 20.4 \\
\hline & & Male Host & All & 89 & 35.5 & 24.5 \\
\hline
\end{tabular}


Table 5. Spearman correlation coefficient $\left(r_{s}\right)$ and the levels of significance of the relationship between the total concentrations of mercury (ng. $\mathrm{g}^{-1}$ ) in the tissues of fish and between concentrations in the tissues of fish and in the parasites, from the middle Itabapoana River, Brazil. ${ }^{(a)}$ Data from non-infested fish. ${ }^{(b)}$ Data from infested fish. $\left({ }^{*} P \leq 0.05\right.$; ** $P \leq 0.01)$.

\begin{tabular}{|c|c|c|c|c|}
\hline \multirow[b]{2}{*}{$\mathrm{x}-\mathrm{y}$} & \multicolumn{2}{|c|}{ Female Fish } & \multicolumn{2}{|c|}{ Male Fish } \\
\hline & (n) & $r_{s}$ & (n) & $r_{s}$ \\
\hline Muscle $^{(a)}$ - Liver ${ }^{(a)}$ & 49 & 0.164 & 22 & 0.073 \\
\hline Muscle $^{(b)}-$ Liver $^{(b)}$ & 35 & 0.109 & 37 & 0.149 \\
\hline Muscle $^{(b)}$ - Parasite & 26 & $0.699 * *$ & 24 & $0.529 * *$ \\
\hline Liver $^{(b)}$ - Parasite & 26 & 0.313 & 27 & $0.424^{*}$ \\
\hline
\end{tabular}

in host muscle to that in the parasites was observed. The low ratio suggests a longer exposure time as metal uptake occurs faster in parasites (Sures, 2001). The expected mercury biomagnification has not always been involved because the parasite may not be regarded as a trophic equivalent of predators (Bergey et al., 2002).

The present study also revealed that $R$. paranensis did not reduce the accumulation of mercury in its fish host as observed by other authors (Sures, 2001, 2003, 2004; Bergey et al., 2002; Sures et al., 2003; Schludermann et al., 2003; Thielen et al., 2004; Tekin-Ozan \& Kir, 2005). For example, when exposed to methylmercury in the laboratory, the grass shrimp Palaemonetes pugio, infested by the isopod Probopyrus pandalicola, accumulated lower concentrations of mercury than their non-infested counterparts (Bergey et al., 2002). However, the parasite P. pandalicola concentrated less mercury than the host, as observed for $R$. paranensis in the present study. Thus, isopod crustacean parasites may not behave as acanthocephalan and cestode fish parasites (Sures, 2004), but they can be useful in assessing the kinetics and ecological circumstances about mercury uptake by themselves and their hosts. Positive and significant associations between mercury levels in host edible part (muscle) and parasite were found.

The present study suggests that $R$. paranensis affected the host accumulation dynamics. Parasitism seems to increase the association between levels of mercury in the liver of fish. However, many ecological and genetic factors can alter heavy metal uptake by host and parasite, and therefore, the generalization of the use of fish parasites to assess environment quality is unlikely. On the other hand, the complexity and ubiquity of host-parasite interactions are good arguments to approach a variety of cases related to pollution.

\section{Acknowledgments}

We thank all the institutions (CNPq, FAPERJ, UFF, UFRJ) and individuals who contributed to this study, in particular Luis Sérgio do Nascimento and José Ricardo Tomaz for assistance with various aspects of the study. We are also grateful to A. Leyva for English editing of the manuscript.

\section{Literature Cited}

Agusa, T., T. Kunito, S. Tanabe, M. Pourkazemi, \& D. G. Aubrey. 2004. Concentrations of trace elements in muscle of sturgeons in the Caspian Sea. Marine Pollution Bulletin, 49:789-800.

Azevedo, J. S. 2002. Dinâmica da interação parasito-hospedeiro entre Riggia paranensis (Szidat, 1948) (Crustacea, Cymothoidae) e Cyphocharax gilbert (Quoy e Gaimard's, 1824) (Teleostei, Curimatidae), no rio Itabapoana, RJ/ES e considerações sobre a biologia reprodutiva do parasito. Unpublished MSc Dissertation. Universidade Estadual do Norte Fluminense, Campos dos Goytacazes, Rio de Janeiro. 111p.

Azevedo, P. de, M. V. Dias \& B. B. Vieira. 1938. Biologia do sagüiru. Memórias do Instituto Oswaldo Cruz, 33:481-559.

Azevedo, J. S., L. Gomes da Silva, C. R. S. Bizerril, M. DansaPetretski \& N. R. W Lima. 2006. Infestation pattern and parasitic castration of the crustacean Riggia paranensis (Crustacea, Cymothoidea) on the fresh water fish Cyphocharax gilbert (Teleostei, Curimatidae). Neotropical Ichthyology, 4:363-369.

Azevedo, J. S., M. P. M. Thomé, L. Gomes da Silva, R. Novelli, M. Dansa-Petretski \& N. R. W. Lima. 2002. Parasitismo de Riggia paranensis (Crustacea, Cymothoidea) em populações de Cyphocharax gilbert (Teleostei, Curimatidae) do norte do Estado do Rio de Janeiro. Boletim do Institituto de Pesca, 28:61-69.

Bastos, P. B. \& V. E. Thatcher. 1997. A redescription of Riggia paranensis Szidat, 1948 (Isopoda, Cymothoidae) based on thirty-two specimens from Curimatid fish of Rio de Janeiro, Brazil, with an Emendation of the genus. Memórias do Instituto Oswaldo Cruz, 92:755-760.

Bastos, W. R. \& H. Kato. 1995. Mercury and methylmercury in fish and human hair from the Tapajós river basin, Brazil. Science of Total Environmental, 175:141-150.

Bergey L, J. S. Weis \& P. Weis. 2002. Mercury uptake by the estuarine species Palaemonetes pugio and Fundulus heteroclitus compared with their parasites, Probopyrus pandalicola and Eustrongylides sp. Marine Pollution Bulletin, 44:1046-1050.

Bidone, E. D., Z. C. Castilhos, T. M. Cid de Souza \& L. D. Lacerda. 1997a. Fish contamination and human exposure to mercury in the Tapajós river basin, Pará State, Amazon, Brazil, A screening approach. Bulletin of Environmental Contamination Toxicology, 59:194-201.

Bidone, E. D., Z. C. Castilhos, T. M. Cid de Souza \& L. D. Lacerda, 1997b. Fish contamination and human exposure to mercury in Tartarugalzinho river, Amapa State, Northern Amazon, Brazil. A screening approach. Water, Air and Soil Pollution, 97:9-15.

Brabo, E. S., E. O. Santos, I. M. Jesus, A. F. Mascarenhas \& K. F. Faial. 1999. Níveis de mercúrio em peixes consumidos pela comunidade indígena de Sai Cinza na Reserva Munduruku, Município de Jacareacanga, Estado do Pará, Brasil. Rio de Janeiro. Cadernos de Saúde Pública, 15:325-331.

Bush, A. O., K. D. Lafferty, J. M. Lozt \& A. W. Shostak. 1997. Parasitology meets ecology on terms, Margolis et al. Revisited. Journal of Parasitology, 83:575-583.

Castilhos, Z. C., E. D. Bidone \& L. D. Lacerda. 1998. Increase of the background human exposure to mercury through fish consumption due to gold mining at the Tapajós river region, Pará State, Amazon. Bulletin of Environmental Contamination Toxicology, 61:202-209.

Da Silva, D. S., M. L. Roulet, H. Poirier, D. Mergler, E. Oliveira dos Santos \& M. Crossa. 2005. Trophic structure and bioaccumulation of mercury in fish of three natural lakes of the Brazilian Amazon. Water, Air, and Soil Pollution, 165:77-94.

De Souza, A. P. L., R. C. S. Muller, J. E. S. Sarkis, C. N. Álves, M. H. S. Bentes, E. Brabo \& E. O. Santos. 2000. Mercury 
contamination in fish from Santarém, Pará, Brazil. Environmental Research, 83:117-122.

Farias, R. A., R. C. Campos \& R. Argento. 2005. Mercury contamination in farmed fish setup on former garimpo mining areas in the Northern Mato Grosso State, Amazonian region, Brazil. Science and the Total Environmental, 348:128-134.

Fisk, A. T., C. A. Wit, M. Wayland, Z. Z. Kuzyk, N. Burgess, R. Letcher, B. Braune, R. Norstrom, S. P. Blum, C. Sandau, E. Lie, H. J. Larsen, J. U. Skaare \& D. C. G. Muir. 2005. An assessment of the toxicological significance of anthropogenic contaminants in Canadian arctic wildlife. Science and the Total Environmental, 351-352:57-93.

Fostier, A.-H., M. B. Falótico, E. S. B. Feraz, A. C. Tomazelli, L. A. Martinelli \& R. L. Victoria. 2005. Impact of anthropogenic activity on the Hg concentrations in the Piracicaba river basin (São Paulo State, Brazil). Water, Air, and Soil Pollution, 166:381402.

Gomes da Silva, L., J. S. Azevedo, M. A. C. Silva Neto, N. R. W. Lima \& M. Dansa-Petrestski. 2005. Effect of the parasitism on sex-specific plasmatic proteins of Cyphocharax gilbert. (Teleostei). Parasitology, 130:653-659.

Huizinga, H. W. 1972. Pathobiology of Artistone trysibia Schioedte (Isopoda,Cyrimatidae) an endoparasitic isopoda of South American fresh water fishes. Journal of Wildlife Diseases, 8:225232.

Lacerda, L. D. 1997. Atmospheric mercury and fish contamination in the Amazon. Ciência e Cultura, 49:54-58.

Lacerda, L. D., E. D. Bidone, A. F. Guimarães \& W. C. Pfeiffer. 1994. Mercury concentrations in fish from the ItacaiúnasParauapebas river system, Carajás region, Amazon. Anais da Academia Brasileira de Ciências, 66:373-379.

Leady, B. S. \& J. F. Gottgens. 2001. Mercury accumulation in sediment cores and along food chains in two regions of the Brazilian Pantanal. Wetlands Ecology and Management, 9:349361.

Lebel, J., M. Roulet, D. Mergler, M. Lucotte \& F. Larribe. 1997. Fish diet and mercury exposure in a riparian Amazon population. Water, Air and Soil Pollution, 97:31-44.

Lechler, P. J., J. R. Miller, L. D. Lacerda, D. Vinson, J.-C. Bonzongo, W. B. Lyons \& J. J. Warwick. 2000. Elevated mercury concentrations in soils, sediments, water, and fish of the Madeira River basin, Brazilian Amazon, a function of natural enrichments? The Science of the Total Environment, 260:87-96.

Lima, N. R. W., J. S. Azevedo, L. Gomes da Silva \& M. DansaPetretski. 2007. Parasitic castration, growth, and sex steroids in the freshwater bonefish Cyphocharax gilbert (Curimatidae) infested by Riggia paranensis (Cymothoidea). Neotropical Ichthyology, 5:471-478.

Lima, A. P. S., R. C. S. Muller, J. E. S. Sarkis, C. N. Alves, M. H. S. Bentes, E. Brabo \& E. O. Santos. 2000. Mercury contamination in fish from Santarém, Pará, Brazil, Environmental Reserch, Sec. A 83:117-122.

Malm, O., W. C. Pfeiffer, W. R. Bastos \& C. M. M. Souza. 1989a. Utilização de acessório de geração de vapor frio para análise de mercúrio em investigação ambientais por espectrofotometria de absorção atômica. Ciência e Cultura, 41:88-92.

Malm, O., W. C. Pfeiffer, R. E. Reuther \& C. M. M. Souza. 1991. Mercury pollution due to gold mining in the Madeira River Basin, Amazon/Brazil. Ambio, 19:11-15.

Malm, O., R. E. Reuther \& W. C. Pfeiffer. 1989b. Arsenic concentration in river sediments from different gold mining areas in Brazil - preliminary results. Proceedings of International Conference Heavy Metals in the Environment, Geneve, 1:130133.
Moraes, L., A. F. Lenzi \& E. B. Luchese. 1997. Mercury in two fish species from Paraná river floodplain, Paraná, Brazil. Environment Pollution, 98: 23-27.

Pfeiffer, W. C., C. M. M. Souza, O. Malm, W. R. Bastos \& J. P. M. Torres. 1989. Mercury pollution in gold mining areas of the state of Rio de Janeiro. Proceedings of International Conference Heavy Metals in the Environment, Geneve, 1:222-225.

Raibaut, A. \& J. P. Trilles. 1993. The sexuality of parasitic crustaceans. Advanced Pathology, 42:307-444.

Sazima, I. \& E. P. Caramaschi. 1989. Comportamento alimentar de duas espécies de Curimata sintópicas no Pantanal de Mato Grosso (Osteichthyes, Characiformes). Revista Brasileira de Biologia, 49:325-333.

Schludermann, C., R. Konecny, S. J. W. Laimgruber, J. W. Lewis, F. Schiemer, A. Chovanec \& B. Sures. 2003. Fish macroparasites as indicators of heavy metal pollution in river sites in Austria. Parasitology, 126:61-69.

Snedecor, G. W. \& W. G. Cochran. 1971. Statistical Methods. The Iowa State University Press. Iowa. 593p.

Storelli, M. M., R. Giacominelli-Stuffler, A. Storelli \& G. O. Marcotrigiano. 2005. Accumulation of mercury, cadmium, lead and arsenic in swordfish and bluefin tuna from the Mediterranean Sea, A comparative study. Marine Pollution Bulletin, 50:10041007.

Sures, B. 2001. The use of fish parasites as bioindicators of heavy metals in aquatic ecosystems, a review. Netherlands Aquatic Ecology, 35:245-255.

Sures, B. 2003. Accumulation of heavy metals by intestinal helminths in fish, an overview and perspective. Parasitology,126:S53-S60.

Sures, B. 2004. Environmental parasitology, relevancy of parasites in monitoring environmental pollution. Trends in Parasitology, 20:170-177.

Sures, B., B. S. Dezfuli \& H. F. Krug. 2003. The intestinal parasite Pomphorhynchus laevis (Acanthocephala) interferes with the uptake and accumulation of lead (Pb-210) in its fish host chub (Leuciscus cephalus). International Journal for Parasitology, 33:1617-1622.

Sures, B., R. Siddall \& H. Taraschewski. 1999. Parasites as accumulation indicators of heavy metal pollution. Parasitology Today, 15:16-21.

Tekin-Özan, S. \& I. Kir. 2005. Comparative study on the accumulation of heavy metals in different organs of tench (Tinca tinca L. 1758) and plerocercoids of its endoparasite Ligula intestinalis. Parasitology Research, 97:156-159.

Thatcher, V. E. 1991. Amazon fish parasites. Amazoniana, 11:263572.

Thielen, F., S. Zimmermann, F. Baska, H. Taraschewski \& B. Sures. 2004. The intestinal parasite Pomphorhynchus laevis (Acanthocephala) from barbel as a bioindicator for metal pollution in the Danube River near Budapest, Hungary. Environmental Pollution, 129:421-429.

Torres, J. P. M., O. Malm, W. C. Pfeiffer, C. M. M. Souza \& M. B. S. Couto. 1991. Heavy metals on sediments from low Paraíba do Sul River watershed. Proceedings of International Conference Heavy Metals in the Environment, Edinburgh, 1:523-526.

Uryu, Y., O. Malm, I. Thomton, I. Payne \& D. Cleary. 2001. Mercury contamination of fish and its implications for other wildlife of the Tapajos Basin, Brazilian Amazon. Conservation Biology, 15:438-446.

Vari, R. P. 1992. Systematics of the neotropical Characiform genus Cyphocharax Fowler (Pisces, Ostrariophysi). Smithsonian Contributions to Zoology, 529: 1-137.

Accepted May 2008 Published June 28, 2008 